\title{
Imagem risco: a mise-en-scène e o "trocadilo" do documentário Estamira
} Risk image: mise-en-scène and the "trocadilo" in Estamira, a documentary

\author{
Imagen "riesgo": la mise-en-scène y el "trocadilo" en el documental \\ Estamira
}

Patrícia Cardoso D’Abreu | patriciadabreu@gmail.com

Universidade Federal do Rio de Janeiro, Escola de Comunicação. Rio de Janeiro, Brasil.

\section{RESUMO}

Este trabalho convida a refletir sobre as representações do feminino que, no documentário 'Estamira', se dão sob o 'risco do real'. Mediada pela câmera, a força do imaginário e da vida ordinária constrói algo comum a partir do que colocamos de nós e do outro em ação. Nessa mise-en-scène, a ética da "in-cenação" do mundo e a estética do documental fazem com que os relatos de uma catadora de Campo Grande, na zona oeste da cidade do Rio de Janeiro, coloquem no campo da tela o que a exclui: lidar com restos. É com os resíduos de um discurso fragmentado, intenso e em fluxo que o outro da protagonista tem que lidar: catadores de sentido, autores e espectadores do filme são colocados diante da descodificação de chaves de leitura sobre o feminino - o que ela chama de "trocadilo" quando aborda temas como sedução, corpo, consumo, patriarcado, gênero e maternidade.

Palavras-chave: documentário; estética; ética; feminino; discurso; gênero; sentido. 


\section{ABSTRACT}

This works invites a reflection on the representations of female identity offered by the documentary 'Estamira' under the 'risk of the real'. Mediated by the camera, the power of the imaginary and collective life build something shared based on what we put in action from ourselves and others. In this mise-en-scéne, the ethics of 'act(ing)' the world and the aesthetics of the documentary allow the stories of a wastepicker in Campo Grande (a poor neighborhood in Rio de Janeiro) to prominently display on the screen that which excludes her: handling the waste of others. Those who interact with the protagonist have to deal with the residues of a fragmented, intense discourse in constant flow: these 'sense pickers', authors and viewers alike are faced with the decoded keys of her perspective on female identity - what she calls "trocadilo" as she discusses themes such as seduction, patriarchy, gender and maternity.

Keywords: documentary; aesthetics; ethics; feminine; discourse; gender; significance.

\section{RESUMEN}

Este trabajo invita a reflexionar sobre las representaciones de lo femenino que, en el documental Estamira, aparecen bajo el "riesgo de lo real". Mediante la cámara, la fuerza de lo imaginario y de la vida ordinaria construye algo común a partir de lo que ponemos en acción de nosotros y del otro. En esta mise-en-scène, la ética de la 'puesta en escena' del mundo y la estética de lo documental hacen que los relatos de una recolectora de residuos de Río de Janeiro plasmen en la pantalla lo que la excluye: lidiar con restos. Es con los residuos de un discurso fragmentado, intenso, fluido, que el otro de la protagonista tiene que lidiar: recolectores de sentido, autores y espectadores de la película se ven frente la decodificación de claves de lectura sobre lo femenino - lo que ella denomina "trocadilo" al aborda temas como seducción, cuerpo, consumo, patriarcado, género, maternidad.

Palabras clave: Documental; estética; ética; femenino; discurso; género; sentido.

Contribuição dos autores: A autora é responsável por todo o resto.

Declaração de conflito de interesses: Não há.

Fontes de financiamento: Não houve.

Considerações éticas: Não há.

Agradecimento/Contribuições adicionais: Não há.

Histórico do artigo: Submetido: 20.out.2016 | Aceito: 02.maio.2017 | Publicado: 30.jun.2017

Apresentação anterior: Não houve.

Licença CC BY-NC atribuição não comercial. Com essa licença é permitido acessar, baixar (download), copiar, imprimir, compartilhar, reutilizar e distribuir os artigos, desde que para uso não comercial e com a citação da fonte, conferindo os devidos créditos de autoria e menção à Reciis. Nesses casos, nenhuma permissão é necessária por parte dos autores ou dos editores. 


\section{Introdução: colocar-se em cena sob o risco do real}

No contexto da midiatização, no qual o imaginário se expande na mesma medida em que perde potência em nome das representações homogeneizantes, é preciso atentar, no campo audiovisual, para propostas nas quais as representações se deem sob o que Jean-Louis Comolli chama de "risco do real". Rodar sob o risco do real implica em uma práxis marcada pela abolição de métodos e ideias minimamente calculadas, como o roteiro, o plano e a trajetória prévia do personagem. Paralelamente, ao contrário de significar uma inocência diante da prática de produção das imagens, optar pelas representações que se dão sob o risco do real marca a força imposta pelo imaginário e pela utopia; força que irrompe das incertezas da vida ordinária, do improvável e do inusitado.

Segundo Comolli², o deslocamento dos roteiros de sua origem técnica para a função de enquadramento das realidades mostra como as previsões e programações regulam os dispositivos sociais e econômicos: ao modo de um código governável, a roteirização da vida tenta aniquilar o real que não consegue calcular e apreender. Instrumentalizada, a roteirização atua em dois vieses: passa a servir às ficções políticas, econômicas, sociais e militares; e faz com que o audiovisual de mercado ajuste o mundo ao que é familiar. Nesse sentido, as abordagens audiovisuais realistas tendem a roteirizar as relações sociais, a intersubjetividade e as fantasias. Tradicionais na teledramaturgia e muito frequentes na diversidade de temáticas da ficção seriada, essas abordagens, de acordo com o autor, fazem com que o documentário se abra ao que ameaça sua possibilidade: 0 real.

Rodar sob o risco do real é direcionar o olhar para as resistências, os restos, as exclusões - a parte maldita que escapa das pré-visões referentes tanto à norma majoritária como à contra-norma minoritária. As representações que o documentário fabrica do mundo podem ser indisciplinadas pelo real que o provoca e o habita: em fricção com o mundo, o documentário também é engajado nele. Atravessado pelas materialidades, o documentário, então, incorre em uma estética que, simultaneamente, ultrapassa e fundamenta seu estatuto de registro. Sob o risco do real, nenhum roteiro sustenta o documentário que opera como práxis. O que é filmado aparece, mas para mostrar o que está fora do projeto de filme, o que não é visível, o fora de campo, o extra-imagem, o impossível de roteirizar. Se o documentário é esta lida com o que está fora, ele é criação, na medida em que vai sempre em busca do que não é reduzido às imagens familiares do mundo, aos programas e aos automatismos do audiovisual-mercadoria precavido pela roteirização em sentido amplo. O que a ficção calculada esconde, o documentário que se dá sob o risco do real, mais que mostrar, faz irromper.

É importante destacar que a questão que se coloca não se refere à oposição entre a ficção e a realidade que se atrela à tipificação das representações, já que a imagem em movimento nasce como dialética entre essas duas instâncias: documento pela ilusão da imagem em movimento ou ficção que documenta a ilusão, o que importa são as relações que essas formas criativas dão a ver. Como verdade classificatória do campo das imagens, a categorização audiovisual estabelece sistemas de regras para a produção e a fruição dos textos cinematográficos, televisivos e videográficos, enquadrando de maneira organizativa as obras. Assim, por serem verdades culturais que orientam as formas de apresentação dos conteúdos em determinados contextos, a divisão das imagens em gêneros ditos ficcionais e documentais interessa ${ }^{i}$ pela fenomenologia

\footnotetext{
i Apesar de a classificação dos gêneros audiovisuais não ser objeto dessa pesquisa, damos aqui, a título de registro, a definição de documentário. Opta-se, aqui, pela que reúne as perspectivas de Jean-Claude Bernardet e Silvio Da-Rin: "Em cada um desses textos, de modos diferentes, delineiam-se três modelos, três matrizes, três formas documentais originárias, cujas metamorfoses constituem os eixos das análises. Eles não chegam a construir contramodelos, propriamente, mas um conjunto de proposições que tentam dar conta de transformações. Obtém-se, assim: 1- Um 'modelo ficcional', calcado da 'função espetáculo', que apresenta a realidade documental como uma ficção, com sua contrapartida em peças experimentais implicadas com uma desarticulação da linguagem documental dominante (Omar); 2- Um 'modelo sociológico', tributário da crença clássica na possibilidade de atingir um real bruto, com sua superação em documentários concebidos como 'discursos' construídos no real (Bernardet); 3- Um 'modelo ilusionista', herdado da 'forte presença do griersonismo' desde a nascença do documentário, cuja problematização se dá com o surgimento de tendências reflexivas que põem em foco os processos de representação documental (Da-Rin) [grifos do autor]. ${ }^{4}$
} 
que tenta compreender o lugar dos sujeitos em sua transitoriedade material (social, política, econômica) e simbólica - ou os lugares que ocupam na vida e nas representações. No encontro com o outro mediado pelo aparelho câmera e apoiados na intransitividade de nossas singularidades e na transitividade das representações, temos a possibilidade de construir algo comum. Quando estamos em cena, somos também espectadores e temos expectativas em relação à performance e à impenetrabilidade do outro com o qual interagimos; posicionados também na dúvida, cremos e questionamos (n)o outro na mesma medida em que somos fiáveis e inconfessáveis diante dele.

No que se refere especificamente ao documentário, Comolli² afirma também que, mais que colocar em cena os personagens, o grande desafio é dar a ver a mise-en-scène deles de maneira a investir no compartilhamento de dramaturgias. Como a imagem é também composta por aquilo que não pode ser capturado pelo aparelho câmera, ela não se resume à mera busca da semelhança como fim, mas também pode ser a busca do comum através das formas - e o 'comum' aqui é o colocar-se em cena na situação de interação criativa. Nesse processo, simulam-se coincidências com a vida e/ou assume-se o risco do delírio inerente a toda representação. De uma maneira ou de outra (e também entre estes polos), a questão se estabelece pelo que quem filma e quem é filmado colocam em ação - a mise-en-scène. Nela, a deformação regrada da ação criativa, da qual fala Paul Ricouer ${ }^{3}$, assume o risco de indisciplinar as cenas do mundo midiatizado marcado pela vida social roteirizada. Nesse contexto de pré-visão das experiências, nesse mundo sem riscos e calculado, evidencia-se a importância do que não é visível: a ética da cena. Em relação ao feminino, esta questão é fundamental. Questionado em suas variações, o feminino irrompe em refigurações bastante distintas, apesar da heteronormatividade masculina que se coaduna a uma estetização dos corpos, principalmente dos corpos das mulheres. Dispersa em uma realidade marcada por desigualdades, a mulher brasileira experimenta um feminino que tenta simular a negociação das diferenças através de uma feminilidade de mercado. Emerge, então, a dúvida: como opera a (re)construção de si que, através da imagem técnica audiovisual e sua mise-en-scène, ultrapassa os determinismos sociais e se dá sob o risco do real?

Rodado durante três anos no aterro sanitário de Jardim Gramacho $o^{\mathrm{ii}}$ e montado durante dois anos de trabalho, o documentário 'Estamira' (cor e P\&B, 2006, Brasil), do diretor Marcos Prado, é um instigante ponto de partida para esta reflexão. Ética e estética documentais, 'Estamira' se configura sob o risco do real a partir dos relatos desconexos de uma catadora de Campo Grande, na zona oeste da cidade do Rio de Janeiro. Depois de trabalhar por mais de duas décadas no chamado 'lixão' de Gramacho, Estamira Gomes de Souza morreu, aos 71 anos, no início da noite de 28 de julho de 2011, de septicemia, no hospital municipal Miguel Couto, na zona sul da cidade. Menos de um ano depois, o 'lixão' foi desativado. É sobre grossas camadas de lixo que Estamira revolve os códigos de leitura do feminino. No mundo transformado em cena, a catadora se mostra através de uma mise-en-scène que se constrói no que ela (conscientemente ou não) desconstrói. Apropriando-se da coesão imaginada e da memória consensual coletiva sobre o feminino, Estamira instrumentaliza o arquivo social para inscrever-se de forma singular. A trama que emerge, o que ela coloca no campo da tela, o que encena, faz irromper exatamente o que a exclui: lidar com restos. Porque é com os resíduos de seu discurso (fragmentado, desconexo, intenso e em fluxo) que nós, o outro de Estamira, temos que lidar. Diante das cenas do imenso lixão do aterro sanitário de Gramacho, os catadores somos nós - autores, técnicos e espectadores - em nossa tentativa de entrelaçar os fios de significado que ela deixa soltos. Como tentativa de apreender a realidade do aterro sanitário de Jardim Gramacho, a narrativa do filme é composta por uma ordem de dialogia e transitoriedade que dinamiza os lugares da autoria, do personagem e do espectador.

ii De acordo com o Instituto Brasileiro de Análises Sociais e Econômicas (Ibase, disponível em http://www.ibase.br) ${ }^{5}$, o aterro sanitário de Jardim Gramacho, em Duque de Caxias, na Baixada Fluminense, funcionou de 1976 a 2012 , quando foi desativado pelo então prefeito do Rio de Janeiro, Eduardo Paes. Na época, cerca de 1900 catadores trabalhavam no local, recolhendo 200 toneladas por dia de material reaproveitável. 
O que se dá a ver a partir da estrutura narrativa do filme é o deciframento do mundo pela descodificação de suas chaves de leitura sobre o feminino: sedução, corpo, consumo, profanação, patriarcado, performance de gênero, objeto da poética, machismo, maternidade. Na expressividade descabida, desviante e singular de Estamira, as formas simbólicas e os significados nos convocam ao (re)construir-com do jogo da representação. Quase um objeto-método, 'Estamira' nos leva a experimentar a exclusão através do que sua linguagem põe em ação em cena, uma vez que, como ela, precisamos catar restos de sentido para reconfigurar o que é despejado na superfície da imagem. Nesse processo, percebemos como o feminino, em vez de ser configurado de forma óbvia (por uma aderência ao 'pré-visto'), descodifica o que o articula, aprisiona e determina. À instigante brutalidade da imagem 'Estamira', respondemos com o rasgá-la em decupagem: processo da prática audiovisual utilizado aqui, de forma invertida, para trilhar o percurso analítico deste documentário.

\section{Estamira: um objeto-método?}

Os primeiros 4 minutos e 30 segundos do filme são em preto e branco; uma sequência de cenas nas quais entram takes de uma garrafa vazia (como se lançada ao mar sem mensagem), uma lagartixa morta, filhotes de cachorro mamando, um pingente-enfeite de meia lua, a vista do interior de um barraco para o lado de fora, a espera no ponto de ônibus, olhos, mãos. Como se fossem rastros, as imagens apontam uma mensagem a ser lançada (a garrafa vazia) na imensidão sem sentido da vida (o animal morto), que codificamos para que possamos renascer no discurso (ninhada mamando) de um mundo codificado (a meia-lua com face humana). O que está por vir é, assim, um ponto de vista (a perspectiva da janela de dentro do barraco) que nos transportará (o ponto de ônibus) para um olhar autoral (olhos e mãos). Neste processo (o longo caminho percorrido a pé até o aterro sanitário de Jardim Gramacho), é preciso lutar contra a própria entropia criativa (caminhões com caçambas imensas trafegam em sentido contrário ao da câmera) na tentativa de iluminar (o céu cinza com sol encoberto) o que nos afeta (cães vira-latas saúdam a chegada da personagem). Para isso, é necessário arriscar-se (ela veste uma espécie de roupa de proteção). Mas esse risco não é unilateral.

Como aponta Comolli', aquele que filma deve não só se expor como também suscitar as armadilhas de quem é filmado: "O homem sabe que é filmado, ele sabe confusamente o que filmar significa, o que ele não sabe muito bem é que nós, os filmadores, não sabemos nada sobre o que ele vai fazer". A personagem-título parece saber disso. Em off, sobre um céu azul profundo no qual voam urubus, ela afirma que sua missão, além de ser Estamira/Estamira (seu nome e título do filme) é a de revelar uma verdade. "Os inocentes, não tem mais inocentes, não tem. Tem esperto ao contrário”, ela diz, segurando uma tábua branca na frente de si. Como que a demonstrar a impossibilidade da inocência diante da câmera, a personagem é metaforizada como uma tela em branco sobre a qual ela mesma evoca o revelar. Um revelar que não é inocente: "Eu não sou comum. Só o formato que é comum”, diz a protagonista.

O "comum no formato" de Estamira é imediatamente assimilado ao que ela, ao longo de todo o filme, irá chamar de "trocadilo": uma espécie de estratégia de mentir, seduzir, cegar e depois jogar no abismo; estratégia esta que sua relação com o feminino irá, aos poucos, revelar. "Por isso que eu estou na carne. Para desmanchar ele com a quadrilha dele todinha”, diz ela. É a carne que, para a personagem, aprisiona o feminino em uma condição subalterna de mulher, condição esta articulada pelo passado patriarcal. Assim, é sobre a montagem de um take de paisagem (sol, morro, serra, montanhas) seguido de um take do lixão, que ela diz: "Paisagem. E a Estamira". Aqui, personagem e cenário se apresentam intimamente entrelaçados. A partir das reflexões de Comolli $^{2}$, este entrelaçamento nos remete às possibilidades mediadoras do audiovisual: "A intenção da mise-en-scène é, antes de tudo, atar. Conjugar, juntar, combinar corpos, luzes, movimentos, durações, músicas, palavras. Todas essas relações estabelecidas podem ser distribuídas na gama inteira das intensidades, podem declinar a escala das relações de força, mas não 
deixam de ser reguladas pela conjunção fundamental do positivo e do negativo, do mais e do menos do campo e do fora-de-campo: ao mesmo tempo respectivamente excludentes, portanto antagonistas, e ligadas, interdependentes, cúmplices”².

Como um trocadilho pelo fato de estar na mira da câmera, seu nome-título sugere a relação indomável entre sua imagem e seu uso do código da língua, o que se insinua pelo take de chamas sobre o qual ela afirma: "A Estamira está em tudo quanto é canto, em tudo quanto é lado. Até meu sentimento. Todo mundo vê Estamira”. De volta ao preto e branco, o filme, como numa autorreferência a seu caráter documental, mostra caminhões descarregando conteúdo. No meio dele, levando um saco com o que catou, a personagem referencia o lixo como produção humana material e simbólica: "Isso aqui é um depósito de restos. Às vezes é só resto e às vezes vem também descuido. Resto e descuido. Quem revelou o homem como o único condicional ensinou ele a conservar as coisas. E conservar as coisas é proteger, lavar, limpar e usar mais. O quanto pode. Quem revelou o homem como único condicional não ensinou a tirar”. Este homem que tira sem conservar é o texto de Estamira sobre um tipo de ética: "O trocadilo (SIC) fez de tal maneira que quanto menos as pessoas têm, mais elas menosprezam. Mais elas jogam fora quanto menos eles têm", analisa. Material e simbólica, esta ética do "trocadilo" se refere não só à produção de lixo pelo humano como também à produção do que, sob a perspectiva social, poderia ser cruelmente chamado de lixo humano, de resto descartado pelo dominante: "Eu sou a Estamira, eu sou a visão de cada um. Ninguém pode viver sem mim, ninguém pode viver sem a Estamira. Eu sinto orgulho e tristeza por isso", ela afirma, em off sobre imagem do voo solitário de um urubu. Estamira remete, então, ao que Simone de Beauvoir ${ }^{6}$ critica como sendo o outro negativo do qual o dominante não pode abrir mão para afirmar-se: a personagem é uma imagem-texto de uma perversa configuração histórica do feminino. Catando lixo, ela diz: "Porque eles, os astros vingativo, ofensível, suja os espaços e quer-me. Quer-me e suja tudo (SIC)”.

Surge a imagem de um trator em uma montanha de lixo: "A criação toda é abstrata. O espaço todo é abstrato. A água é abstrata, o fogo é abstrato, tudo é abstrato. E a Estamira também é abstrata”, analisa a protagonista. Fazendo referência direta a um mundo codificado, a personagem se vale da opacidade da própria imagem; imagem esta cujo potencial de transcendência e subjetividade não lhe escapa: "Visivelmente, naturalmente, se eu me desencarnar, eu tenho a impressão que eu serei muito feliz. E talvez eu poderia ajudar alguém”. Configuração engendrada por ela e pelo diretor do filme e que coloca suas respectivas ações em cena (encenar e in-cenar), as imagens de Estamira mostram o lixão mais como um campo simbólico trabalhado do que como uma superfície tecnicamente estetizada: "A coisa que eu mais adoro é trabalhar", confessa. É o trabalho de catadora no lixão de Gramacho que, como componente da mise-en-scène, paradoxalmente tira Estamira de uma indigência socialmente imposta e muito mais poderosa que ela: "Tem o eterno, tem o além e tem o além dos além". Essa força social que a empurra para a indigência surge na imagem de um corpo morto de mulher no lixão. E mostra, como aponta Gilles Deleuze, algo além de uma verdade aparente: "Uma situação ótica e sonora não se prolonga em ação, tampouco é induzida por uma ação. Ela permite apreender algo intolerável, insuportável. Não uma brutalidade como agressão nervosa, uma violência aumentada que sempre pode ser extraída das relações sensório-motoras da imagem-ação. Tampouco se trata de cenas de terror, embora haja, às vezes, cadáveres e sangue. Trata-se de algo poderoso demais, ou injusto demais, mas às vezes também belo demais, e que portanto excede nossas capacidades sensório-motoras" ${ }^{1}$.

Entrando em jogo com a violência de sua invisibilidade social - que é análoga à violência do corpo de mulher no lixão - Estamira evoca como a produção de imagem e memória é algo que temos em comum: "O homem, depois que ele fica visível, depois que nasce, ele, depois que ele desencarna, a carne, se for pro chão, derrete. Fica só os ossos e os raios, os cabelos. E aí ele fica formato: a mesma coisa, só que fica transparente, fica perto da gente. Meu pai tá perto de mim, minha mãe. A gente fica formato transparência e vai como se fosse um pássaro, voando. Lá em casa eu vejo é muito. Vai muito lá em casa”, diz Estamira. 
Na casa dela, em Campo Grande, a imagem volta a ser em cores para dar voz às suas lembranças, que ela narra sem olhar diretamente para a câmera e depois de parecer fazer uma oração em uma língua indecifrável - que ressurgirá durante vários momentos do filme. "Eu nasci no sete do quatro do quarenta e um, a carne e o sangue. E o formato par. Formato homem par: mãe e avó”, ela diz, como que para afirmar o vínculo do feminino pela maternidade. "Eles levaram meu pai no quarenta e três", ela prossegue. "Aí, nunca mais meu pai voltou. Meu pai chamava eu de tanto nomezim (SIC), de tanto nome engraçado”, divaga. Aqui, a nomeação evoca a memória afetiva de Estamira, que manuseia um monóculo antigo no qual se visualiza um cromo através de uma lente, enquanto ela fala da dor em relação à morte do pai. A memória do vínculo com a mãe mostra também a condição de um feminino que se reconfigura no tempo: "Coitada da minha mãe, mais perturbada que eu. Bem, eu sou perturbada, mas lúcida, porque eu sei distinguir a perturbação. E a coitada da minha mãe não conseguia mas, também pudera, eu sou a Estamira”, ela avalia, em off, enquanto a câmera mostra um caco de espelho que a reflete olhando o monóculo. Há, aqui, na fala da protagonista, a menção da passagem do corpo físico para a abstração do código: "Tem o controle remoto superior, natural, e tem o controle remoto artificial. O controle remoto é uma força, assim, uma força quase igual à da luz, a força elétrica, a eletricidade. Na carne e no sangue tem os nervos. Os nervos da carne sanguínea vêm a ser os fios elétricos", analisa Estamira. Nesta passagem, as naturezas são disciplinadas: "Agora, os deuses, que são os cientistas, técnicos, eles controlam. Os cientistas, determinados trocadilhos (SIC), eles conseguem. Porque o controle remoto não queima, torce. O cientista tem um medidor que controla igual o ferro [de passar roupa, que entra como insert]. É tão simples, né?!".

A associação a esta ideia de criação é feita pelo lettering que entra, em seguida, sobre a imagem do chorume que borbulha no lixão: nele está escrito "Natal de 2000". É quando ela, irônica, diz para a câmera: "Agora tem o registrador de pensamento, você já viu? Ora, você não viu, rapaz?! Você tá brincando comigo... Puxa vida, é a mesma coisa do eletroesferograma (SIC)". Levando à associação entre 'criação' e 'criatividade', a sequência se completa com a afirmação de Estamira de que tudo que nasce é natal. E ela diz: "Eu revelei quem é deus. Porque eu posso, felizmente, sem reprovação, sem repugnância, com muito orgulho. Revelei porque posso, porque sei”. O que Estamira parece saber é a força que (como a tempestade que o filme começa a mostrar) têm a nomeação, o discurso, os textos que castram a crítica do homem. "Eu não tenho raiva de homem nenhum. Eu tenho raiva é do trocadilho (SIC), do esperto ao contrário, do mentiroso, do traidor. Desse é que eu tenho raiva, ódio, nojo", ela vocifera. E prossegue: "Eu já tive dó de Jesus. Agora não tenho mais dó. Não tenho mais dó de Jesus não. Eu já tive dó de escravo, não tenho mais dó de escravo também não". A estas nomeações esvaziadas de humanidade, a personagem inscreve suas paixões: "Me chamam de Jesus, me chamaram de sangue de barata, me chama de sangue de Cazuza, me chamaram de Maria que é a mãe de Jesus. Que deus é esse? Que Jesus é esse? Quê que é isso?”, questiona a catadora.

Nesse ponto, o documentário remete ao que Comolli ${ }^{2}$ chama de "empilhamento das representações" que suscita o caráter político do cinema, uma vez que "a arte da mise-en-scène sabe desentocar as mise-en-scènes dos poderes dominantes, assinalá-las, sublinhá-las, esvaziá-las ou desmontá-las”². Como a tempestade mostrada pela câmera, Estamira se mostra como uma imagem-texto desprovida das ilusões sobre as quais se sustentam as mise-en-scènes das quais fala o autor: "Vocês acham que eu sou feiticeira? Eu sou feiticeira, mas eu não sou feiticeira falsária e nem perversa, não. Mas eu sou ruim. Perversa eu não sou, mas ruim eu sou. Sou ruim e não vou deixar de ser ruim, sem perversidade. Na cobrança. Eu conto até três, eu conto até dez, eu tenho o controle superior", divaga a personagem. O controle que Estamira diz possuir parece ser sobre o sentido, que ela coloca em ebulição como a imagem do chorume que borbulha sob a chuva: "O além dos além é um transbordo (SIC). Você sabe o que é um transbordo? É toda coisa que enche, transborda. Então, o poder superior real, a natureza superior, contorna tudo pra lá, para aquele lugar. Assim, como as reservas... Tem as reservas. Na beirada. Na beirada, ninguém homem pode ir lá". Face à ordem 
discursiva, o "poder superior real" da vida e das experiências irrompe como explosão dos limites (beiradas) do sentido; explosão esta que não se acessa como código e sim como vivência. Mas essa vivência pode ser refigurada, metabolizada: é o que sugere a imagem de Estamira cozinhando enquanto fala. De capa de chuva amarelo-sol, a personagem se refere a "astros horrorosos irrecuperáveis" que são fixados nesses limites, nessas 'beiradas' nas quais "sanguíneo nenhum pode ir”. Manuseando um jornal, em seguida, Estamira é a imagem-texto das significações unívocas e desumanas que impõem sentido aos absurdos, desigualdades e desumanidades que desafiam a própria imaginação humana. É por isso que, em close, ela afirma: "Vocês não vão entender em uma só vez, que eu sei. Por isso que eu ainda estou aqui visível, formato homem. Formato homem par. Não tô em formato homem ímpar. Formato homem ímpar é vocês. Formato par é mãe. Mãe é formato par. E o ímpar é o pai”.

Nessa evocação explícita da maternidade, Estamira se atrela à ideia de feminização do mundo apontada por autores como Alain Touraine ${ }^{8}$ e Raquel Paiva'. Mas isso não se dá pela obviedade do 'par' biológico mãefilho (que se revelará problemática para ela, ao longo do filme), mas sim pela característica de recomposição que o feminino dá ao mundo, em oposição à decomposição do mundo dominado pela masculinidade. Ao mesmo tempo, o formato homem-par ao qual ela se refere parece estar na significância que a imagem, como duplo (Estamira pessoa encenando 'Estamira' imagens), pode promover de forma muito mais dinâmica que a mera codificação representada pelo "formato homem-ímpar" dos que operam o aparelho câmera. E ela reforça a opacidade de sua imagem, seu formato homem-par, sua significância: "Eu transbordei de raiva. Eu transbordei de ficar invisível com tanta hipocrisia, com tanta mentira, com tanta perversidade, com tanto trocadilho (SIC). Eu, Estamira”, conta. Dessa forma, sua encenação descodificadora dos sentidos opressores aponta para a irracionalidade do homem que não questiona as configurações do mundo codificado: "As doutrinas que expõe o homem ao ridículo e fez o homem pior que os quadrúpulos (SIC). Então, que deixassem o homem como antes de ser revelado, como o único condicional”, diz Estamira. O questionamento às representações é aqui bem marcado pela personagem, que critica os textos (doutrinas) que transformam o homem em animal enquadrado (quadrúpulos). Essa associação se revela na sequência seguinte, aparentemente desconectada da anterior, mas na qual um dos catadores do lixão apresenta uma matilha por seus nomes próprios enquanto se desloca com facilidade pelo lixo, cujo mapeamento parece ter sido interiorizado por ele. "Eu não gosto de falar lixo não. É cesto", corrige Estamira. Em seguida, ela dá sua própria explicação para a formação do chorume: "Tem gente que não se habitôa (SIC) com ele, não dá conta”. É essa metabolização dos restos (que acabam se transformando no chorume borbulhante) que parece estar relacionada à lógica da catadora - em uma fala, no fim do filme, ela afirma que parece "ter Sonrisal borbulhando" dentro de sua cabeça. É essa consciência que a faz revoltar-se contra os preceitos religiosos, o que a leva a desentendimentos com os filhos.

Na sequência seguinte, o filme assume o tradicional testemunho documental quando a filha de Estamira, Carolina, explica o comportamento da mãe. Paradoxalmente, a sanidade da filha é mais chocante que os devaneios da catadora, que mostra revolta com as univocidades religiosas, rejeitando-as como pontos de vista. "Ponto de vista porra nenhuma, olha essa porra aí!", grita Estamira, atirando um livro evangélico contra a filha, que a acusa de ser contrária à figura religiosa de Jesus Cristo. "Deixa de ser otária, deixa de ser abestalhada! Eu não sou contra ele, pelo contrário: eu tenho dó! Quem falou que eu não gosto dele? Só não é isso que vocês pensa (SIC)!", revolta-se a catadora. Com o filho mais velho, Hernani, não é diferente. Depois que ele e a irmã discordam sobre a possibilidade de internação da mãe (Hernani é a favor), Carolina relata - em off, sobre uma sequência de fotos - a vida conjugal dos pais, revelando que eles se separaram porque Estamira não aceitava os relacionamentos extraconjugais do parceiro. "A culpa é do hipócrita, mentiroso e esperto ao contrário. Que joga pedra e esconde a mão”, diz Estamira. Tanto como uma associação à figura do pai de Carolina, há aqui também uma associação com a imagem social que 
os indivíduos constroem de si: delineadas pela hipocrisia das relações, essas imagens seriam estilhaçadas pelos próprios indivíduos que, então, se tornariam dissimulados.

Ao longo do filme, Estamira mostra que não é uma mulher que odeia os homens; ao contrário, eles são seus amigos, companheiros, ex-maridos e amores do passado. Ela ri com eles, se diverte e não mostra moralismos ao interagir e achar divertido o fato de eles se masturbarem. Como alegoria à sexualidade, a sequência seguinte mostra Estamira colocando uma máscara e cantando uma marchinha de carnaval, que é repentinamente interrompida quando ela mesma alerta: "Me respeita, cabra safado!". A protagonista, então, tira a máscara e diz, triste: "Já era, matou todo mundo". Transitividade entre o vivificante e o aniquilante e entre o alegre e o moralista, a fantasia, na encenação da catadora, não é ilusão e sim forma criativa. Das relações de Estamira com os homens, o filme traz, além do filho Hernani, o catador João. Lado a lado, ele e ela brincam e dizem que casariam um com o outro. É quando a protagonista começa a cantar em seu código indecifrável. A câmera, em plano fechado na expressão triste dela, mostra uma imagem do indizível. Ao fim, ela diz "eu te amo" e a montagem do filme tenta significar o inaudito através de uma sequência, em preto em branco, de fotos de Estamira com o ex-marido. Em off, sobre essas imagens, ela (supostamente) acusa: "Mas você é indigno, incompetente. Eu lamento. Eu te amava".

De volta ao take anterior, em cores, João sai de cena e ela prossegue: "Mas você é indigno. Incompetente. Otário. Pior do que um porco sujo. Advirta-se. Faça bom prato. Deixa-me! Eu prefiro". O que ela parece preferir também é expresso em seu código indecifrável, como se fizesse alusão a um desejo inapreensível, impossível de ser colocado em palavras, impossível de ser codificado, significado. Mas ela prossegue: "Nunca mais encostarás em mim”. E volta para sua língua própria, em off, sobre a cena de dois cães que brincam, tentando tomar um brinquedo um do outro - imagem pueril sobre o jogo entre Estamira e espectadores. Em seguida, fotografias aéreas do lixão são narradas pelo canto indecifrável da personagem, canto este que vai descendo para background enquanto sobe o som de uma música. Aqui, fica claro que Estamira descodifica o mundo no qual escolhe viver. Para além de uma estetização do campo sonoro fílmico, este trecho remete à escuta da câmera, analisada por Comolli: "É preciso filmar de muito perto, como uma orelha, mais do que como um olhar. É preciso que a câmera esteja no alcance da mão (daquele que é filmado), que se possa tocá-la. [...] A câmera escuta. Que eles atuem, então, a partir de suas próprias palavras, ouvidas por nós, aceitas, acolhidas, captadas. Não as minhas palavras, mas as deles. Posso dizê-las de novo no lugar deles, mas são deles, e quanto a isso ninguém se engana. Aqueles que filmamos são, antes de tudo, tomados em suas palavras, e é com essas palavras, com a língua e com a fala deles, que eles se sabem apreendidos pela câmera. Tomada de imagens sim, que é vivida como uma tomada de linguagem”".

Em momento algum, o lixão é mostrado ou narrado como algo imposto a ela, mas sim como uma escolha. Em ação nas cenas, o aterro sanitário de Gramacho é um dos panos de fundo nos quais ela se inscreve (sua casa e o posto de atendimento psicossocial são outros): em ação nas cenas, o aterro é um leitmotiv, o fio imagético ao qual o diretor se apega para tecer sua narrativa com e de 'Estamira'. Evidentemente, a materialidade da catadora é atravessada e determinada pela perversidade da produção de miséria contemporânea que lhe tira outras opções além do trabalho no lixão. Mas Estamira é infinitamente maior que esta perversidade que (talvez para o espectador e não para ela) a vitimiza. Nada a determina, nem mesmo o que a oprime - esta é sua maior beleza - e sua potência descodificante é explicitada por seu canto sem letra, o texto-imagem de sua escolha pela liberdade avessa ao conformismo. Como contraponto a esta força - muitas vezes metaforizada pelo vento -, as imagens documentais do lixão se sucedem e entra mais um depoimento em off de Carolina sobre a vida da mãe, os perigos pelos quais passou e a insistência dos filhos para que abandonasse o lixão. Em seguida, ainda com imagens em preto e branco, Carolina passa por um portão no qual há uma placa em que se lê "cuidado, vira-latas neuróticos". É nesse ponto que ela começa a contar sobre os estupros que a mãe sofreu, sobre o trauma e a revolta consequentes deles. Em uma alusão explícita à dualidade animalidade-racionalidade, a placa nos dá a ver que as experiências 
brutais sofridas por Estamira dão a ela uma consciência que só se realiza pela descodificação do mundo, pela descodificação das chaves de leitura hipócritas do mundo. Carolina, então, afirma que a mãe, religiosa até ser violentada, passou a ter alucinações depois de sofrer os estupros, quando começou a repetir a frase "eu e eu e o poder". Nesse ponto da fala de Carolina, a montagem faz o insert de um coqueiro, ao qual seguese um close de Estamira, que reclama: "Trocadilo (SIC) safado, canalha, assaltante de poder, manjado, desmascarado. Me trata como eu trato, que eu te trato. Me trata com o teu trato, que eu te devolvo o teu trato. E faço questão de devolver em tripulo (SIC)!". O 'trípulo' de Estamira é sua tríplice mimese: é sua força reconfiguradora contra o que lhe "assalta o poder"; é o jogo que sua linguagem dá a ver entre as experiências que prefiguram sua entropia criativa, as chaves de leitura hipócritas dos textos que compõem o mundo pelo disciplinamento do feminino e à necessidade de significância à qual ela nos impele. Seu 'trípulo' é, para além da mera troca de palavras e sentidos, o troco que ela devolve ao devoramento do humano, à cultura do consumo e à opressão ao feminino.

"Que Deus é esse? Que Jesus é esse, que só fala em guerra e não sei o quê... Não é ele que é o próprio trocadilho (SIC)? Só pra otário, pra esperto ao contrário, bobagem, bestaiada (SIC). Quem já teve medo de dizer a verdade largou de morrer? Quem fez o que ele mandou largou de morrer? Largou de passar fome? Largou de miséria?”, questiona a protagonista. Suas indagações remetem à questão de que o dizer, o colocar em código, não evita a morte: o que Estamira significa é o nosso próprio esforço de dar sentido à vida pela comunicação, pela comunhão. Segundo Comolli, a capacidade que o filmado tem de colocar em cena, de produzir a mise-en-scène de si mesmo, corresponde ao fato de dominar e brincar com o medo que o observador tem de ser observado e ser reconduzido à inocência primeira da magia cinematográfica inicial, no desejo de filme: "Desejo do outro lado, no real, no outro como aquele que pode ser sujeito do filme. Filmar aqueles que se dispõem a isso, que se entregam por meio de um dispositivo que eles propõem e pelo qual eles seriam também - ou primordialmente - responsáveis"². Este esforço permeia o filme em quase toda a sua duração. Mas esse não é um problema para Estamira: sua peleja na lida com o lixão e com sua saúde mental já são problemas suficientes. Que pelejem, também, os que se colocam em ação na cena com ela. Por trás da câmera ou diante da tela, continuamos a ser instigados a catar restos de sentido e a transformar imagens em textos de forma a perseguir alguma lógica. Pervertido pela atribuição de sentido a tudo, nosso culto às literalidades e legibilidades nos coloca em ação com as cenas do filme. Jogados na mise-en-scène de 'Estamira', somos desafiados a entrar em seu jogo de representações e significações - e sua linguagem, que nos coloca como catadores de 'restos' de sentido, funciona como um dispositivo.

"Não adianta. Ninguém, nada, vai mudar o meu ser! Eeu sou Estamira aqui, lá, no inferno, nos infernos, no céu, no caralho, em tudo quanto é lugar, não adianta! Quanto mais essas desgraças, esses piolho (SIC) de terra suja, amaldiçoada, excomungada que renegou os homens como único condicional, mais ruim eu fico, mais pior eu sou (SIC)!", ela vocifera. Imagem-texto de resistência aos sentidos impostos, Estamira investe contra o código na criação de si. Sua autorreferencialidade em nenhum momento é agrafia do outro: ao contrário, ela depende da escrita religiosa, científica e médica para que seu discurso, pela transitividade entre vinculação e distância, tenha a força daquilo que Ricouer ${ }^{10}$ chama de significância. "Eu sou a beira do mundo. Eu sou Estamira. Eu sou a beira. Eu tô lá, eu tô cá, eu tô em tudo quanto é lugar e todos dependem de mim. Todos dependem de Estamira”, diz a personagem-título. Nesse ponto, a montagem faz mais um insert do coqueiro, imagem que remete ao texto "eu e eu e o poder". A imagem-texto do coqueiro é também passagem para que Hernani dê seu testemunho sobre a vida da mãe. O foco de sua fala (toda em off sobre imagens dele em preto e branco) é um dos surtos nos quais Estamira teve que ser contida pelo corpo de bombeiros e que levou à peregrinação por hospitais em busca de atendimento, culminando em sua recusa a ser internada e na violência física contra o filho. Ele, então, a deixou no hospital. Como um juízo de valor, o take que se segue à fala de Hernani não é o do coqueiro (“eu e eu e o poder"), mas sim o de uma bananeira por trás de um arame farpado. A mais essa imagem-texto, segue-se, agora em cores, a revolta de 
Estamira contra as contenções: "A desgraçada da família Itália, junto com aquele filho meu, me pegaram aqui dentro como se eu fosse um uma fera, um monstro algemado. E aquele meu filho ficou contaminado pela terra suja, pelo baixo nível, pelo insignificante”, reclama a catadora. A alusão à falta de sentido das convenções é explícita aqui, nesta passagem na qual o texto-imagem de Hernani compõe uma figura de mãe desconectada do imaginário: para além de mãe, Estamira é o feminino que não "se contamina" pelo "insignificante".

Prosseguindo contra o "insignificante", a catadora comenta seu trabalho no lixão. "Eu não vivo por dinheiro, eu faço dinheiro. Eu é que faço. É você que faz. Eu não vivo pra isso, por isso. Eu que faço. Não tá vendo eu fazer?!”, ela explica. Mas seu corpo não é imune ao trabalho no lixão e Estamira sente dor: "Controle remoto atacou. Os astros negativos, ofensível (SIC), eles tá (SIC) pelejando pra ver se atinge uma coisa que se chama de coração. Meu. Ou então, a cabeça. Eles tão fudido (SIC). Tão poderoso é o contrário, o hipócrita, o safado, o traidor, mentiroso, manjado, desmascarado, que se mete com a minha carne visível, com a minha camisa sanguínea, carnifa (SIC). É a Estamira. Eles tá fudido comigo até pra lá dos quintos dos inferno (SIC)", ela conta. Essa materialidade do corpo incorre no absurdo quando a catadora seleciona comida no lixão. "Amanhã , por causa disso, eu vou preparar uma bela duma macarronada. Uma carga muito boa. Às vezes, fica melhor que no restaurante. Pra quem sabe preparar, né?!", diz Estamira, manuseando o lixo despejado enquanto seleciona comida. A alusão à metabolização dos restos materiais, apesar de chocante, funciona como reforço para a fala dela que, em close, vem a seguir: "Tem o lúcido. O lúcido é isso aqui [ela limpa os dois olhos]. Tem o ciente. O ciente é o saber. Do qual Jesus não sabe ler nem escrever, mas ele aprendeu toda a coisa de tanto ele ver ou elucidar". Estamira parece apontar a impossibilidade que o homem, como criatura, tem de decodificar e codificar o que lhe é imposto como destinal, o que só seria possível pela experiência da reconfiguração do que é "in-formado". Isso, por sua vez, não se esgota na mera racionalidade: “A tua lucidez e não te deixa ver...”, ela cantarola. "Agora, por exemplo, sentimentalmente, visivelmente e invisivelmente formato, transparente conforme eu já te disse, eu estou num lugar bem longe", divaga a personagem. Imagem da imaginação, Estamira questiona as nomeações e ratifica a força da experiência singular: "Estamira tá longe. Estamira está em todo lugar. Estamira podia ser irmã, ou filha ou esposar de espaço, mas não é. Vocês não aprendem na escola. Vocês copiam. Vocês aprendem é com as ocorrências. Eu tenho neto com dois anos que já sabe disso. Tem de dois anos, ainda não foi na escola copiar hipocrisias e mentira e charlatagem (SIC)".

Benjaminiana ${ }^{11}$, a fala de Estamira conclama a não herdar as representações e sim construí-las. Como se exemplificasse a imitação, a cópia, ela, na fala posterior, imita a linguagem de rádio: "Dezenove, três, pois. Dezenove, três, pois”. Segue-se, então, a simulação que ela faz de uma conversa telefônica, por meio de sua língua indecifrável. Nesta simulação, o destaque é para a expressividade de Estamira, que imprime certo sentido ao que diz pela entonação que dá ao dizer. Nesse ponto do filme, a linguagem codificada de Estamira é diretamente relacionada à sua saúde mental, já que a montagem dá vez a uma sequência, em preto e branco, no posto de assistência psicossocial de Nova Iguaçu, cidade do Rio de Janeiro. Estamira está misturada à multidão de pacientes. Em off, com a voz arrastada, ela explica: "Eu escuto os astros, as coisas, os pressentimentos das coisas. Tem hora que eu fico pensando como é que eu sou lúcida. Estamira sem carne, invisível, vê e sente as coisas tudinho (SIC). Por isso que eu sou Estamira mesmo, né?! Mas tem vez que eu fico pensando: eu não sou um robô sanguíneo, eu não sou um robô". Estamira parece manter sua identidade e, apesar de sua condição mental, não se entrega ao automatismo, o que vai ficar mais claro em seu discurso sobre a medicação que lhe foi receitada. Nesse momento, as imagens voltam a ser em cores. $\mathrm{O}$ take é o de uma teia de aranha. Estamira ri e, em seguida, reclama da médica que receitou seus remédios ter feito alusão a deus: "Eu fiquei muito decepcionada, muito triste, muito... Profundamente com raiva dela falar uma coisa daquela. E ela ainda disse sabe o quê? Que deus livrasse ela, que isso é magia, telepatia, a mídia e o caralho. Porra, porra, pra quê? Ela me ofendeu demais da quantia (SIC)". 
No decorrer da fala de Estamira há o insert de uma lâmpada em frente à qual há a mesma teia de aranha, numa alusão à consciência que ela tem sobre o disciplinamento concernente à prática psiquiátrica. Em seguida, as imagens de um cartão no qual se lê "programa de saúde mental" antecedem a fala da catadora, que ressignifica as ideias de "programa" e de "saúde mental" ao se referir à psiquiatra que a atendeu: "Eu conheço médico, médico, médico, médico direito, viu? Ela é copiadora. Eu sou amiga dela, eu quero bem a ela, eu quero bem a todos, mas ela é copiadora”, diz a personagem. E prossegue: "Eles estão dopando quem quer que seja com um só remédio. Não pode! O remédio? Quer saber mais que a Estamira? Presta atenção. O remédio é o seguinte: se fez bem, para, dá um tempo; se fez mal, vai lá, reclama como eu fiz três vez (SIC)". Ao avaliar quem a avalia, a catadora vai ao encontro das relações entre olhante/olhado e objetividade/subjetividade que, segundo Deleuze", se estabelecem no cinema: "É necessário precisar o que são objeto e sujeito nas condições do cinema. Por convenção, chama-se objetivo o que a câmera 'vê' e subjetivo o que o personagem 'vê'. Tal nomeação só ocorre no cinema, não no teatro. Ora, é certo que a câmera vê o próprio personagem: é uma mesma personagem que ora vê, ora é vista. Porém, é ainda a mesma câmera que apresenta a personagem vista e o que ela vê. Pode-se pois considerar que a narrativa é o desenvolvimento dos dois tipos de imagem, objetivas e subjetivas, a relação complexa delas que pode resultar em antagonismos mas deve se resolver numa identidade $\mathrm{Eu}=\mathrm{Eu}$ : identidade da personagem vista $\mathrm{e}$ que vê, mas também identidade do cineasta-câmera que vê a personagem e o que a personagem vê".

Em outro insert da lâmpada, Estamira prossegue em sua análise sobre o tratamento psiquiátrico e critica: "Eles tão copiando! O tal de diazepam ${ }^{i i i}$, então! Entendeu?! Se eu beber diazepam, se eu sou louca, visivelmente, naturalmente, eu fico mais louca. Entendeu agora? O tal do diazepam! Não! Eles lá só copeia (SIC)! Uma conversinha qualquer e só copiar e tó... Ah, o quê é que há, rapaz? Ah, isso não pode não senhor! Como é que eu vou ficar todo dia, todo mês, cada marca (SIC) e eu vou lá apanhar o mesmo remédio? Não pode! É proibido! Não pode! Entendeu agora? E eu não estou brincando, eu tô falando sério!". Nesse ponto do filme, a protagonista fala diretamente para a câmera, não só questionando a ética médica como também tentando reforçar a veracidade de seu discurso. "Tudo quanto é remédio que ela passou pra mim, eu bebi. A quantia é o limite. Toda coisa tem limite! Esses remédios são da quadrilha da armação do dopante pra cegar os homens, pra querer deus! Deus falsário!”. E numa crítica direta à prática médica que não trabalha a autonomia, mas sim a submissão medicamentosa, ela vocifera, seguida por mais um take da teia: "Esses remédios são dopante pra querer deus falsário! Ela falou que deus que livrasse ela: o trocadilo (SIC) é ela!”, irrita-se.

Surge, então, no filme, mais uma filha de Estamira: Maria Rita. A entrada da personagem em cena se dá, em preto e branco, pelo testemunho de sua mãe adotiva, que se refere à catadora como "mendiga" e conta que Hernani permitiu que a menina, aos 7 anos, fosse entregue a ela. Seguem-se imagens da casa de Estamira: Maria Rita vai visitá-la, as duas ficam felizes, são muito afetuosas uma com a outra; a moça relembra, com tristeza, a vida no lixão. E confessa: "Se eu pudesse, eu não tinha saído de perto da minha mãe”, diz Maria Rita. A cena é de intimidade em família e de ternura maternal. Mas sofre uma virada súbita quando Hernani começa a evocar um deus supremo e a citar trechos da Bíblia. "Que deus porra nenhuma! Você nem sabe o que é deus! Meu ouvido não é privada! Otário! Otário! Vai tomar no cu!”, xinga a catadora. Revoltada com o discurso religioso, Estamira explode a ideia de pai tão cara à cultura do patriarcado. Escolha ou não do processo de montagem, o curioso é que, ao longo de todo o filme, nenhum dos xingamentos proferidos por Estamira faz referência à maternidade: a maioria deles é relacionada à contenção: "Dentro da minha casa! Dentro da minha casa, pô! Eu não caguei essa casa não! Não foi

iii De acordo com o Dicionário de Especialidades Farmacêuticas (D.E.F. 2014), as propriedades ansiolíticas, miorrelaxantes e anticonvulsivas do diazepam fazem com que ele seja prescrito para o alívio de ansiedade, agitação e tensão psiconeuróticas e de distúrbios de estresse emocional, como a insônia. Sua funcionalidade como relaxante muscular faz com que ele seja aplicado até em casos de tétano. O diazepam é uma substância que só pode ser comercializada com retenção de receituário especial e identificação do usuário. 
cagado não, foi trabalhado, suado, dia e noite, no sol e na lama. Vai pro inferno, vai pro caralho, vai tomar no cu! Vai tomar no seu cu, entra dentro do cu da sua desgraça!”, ela esbraveja. O filho vai embora e, sobre um close de Maria Rita terminando a refeição preparada pela mãe, Estamira diz, em off: "Esses pastor todinho é vigarista, vadio, vagabundo, todos eles (SIC)! Pior do que os padres!”. A imagem-texto da filha comendo remete aos aspectos devoradores da fala da catadora, que não comunga dos dogmas religiosos que controlam as subjetividades pela contenção.

"Eu sou louca, sou doida, sou maluca, sou advogada. Sou essas quatro coisa (SIC). Mas, porém, consciente, lúcido e ciente sentimentalmente", diz Estamira, em off, sobre um close dela mesma. O campo sonoro da cena traz uma tríplice nomeação da condição mental da personagem (louca, doida, maluca) atrelada ao "e", que indica diferença, para somar-se ao fato de ela advogar por si mesma. Esta perspectiva parece se confirmar na continuidade da fala da personagem: "Só comecei revelar no 86 (SIC), revelar de verdade mesmo porque era muito abuso. Por isso que eu tô revelando que o cometa tá dentro da minha cabeça ${ }^{i}$. Sabe o que significa a palavra cometa? Comandantev . Comandante natural. Comandante”, ela conta. Segue-se a língua indecifrável de Estamira como que a apontar o tanto que há de incontido em seu desejo de autonomia. "A constelação, todo meio, eles ficou (SIC) com raiva do cometa. Há determinados astros perversos, astros negativos, que está (SIC) com raiva do cometa porque o cometa achava que ele não deveria procurar uma carcaça como a minha. Aí volta lá procurar uma carcaça, como? Maria raelense (SIC), mãe de Jesus, que concedeu (SIC) Jesus, Jesus filho de Davi carvalhense (SIC)”, ela divaga. É sua 'carcaça' - profanada, estuprada, que sente dor - a escolhida para ser o meio de revelação. Afirmando o feminino pela 'carcaça' que nega a feminilidadepadrão, Estamira parece descodificar a chave de leitura de uma das imagens mais fortes do imaginário sobre o feminino: a Virgem Maria, figura contra a qual ela não blasfema. A revolta de Estamira é contra a ideia do pai. Nesse momento, ela volta a sua língua indecifrável e diz para si mesma: "Mantenha controle, mantenha controle”. Só quem parece ‘controlar' Estamira é ela mesma - ou seu 'comandante' interior. É em uma alusão ao patriarcado que Estamira, em off sobre imagens noturnas de despejo de caminhões de lixo, questiona: "Isso aqui é um disfarce de escravo. Escravo disfarçado de liberto, de libertado. Olha, a Isabel, ela soltou eles, né?! E não deu emprego pros escravos. Passam fome, comem qualquer coisa, igual os animais, não têm educação. Então, é muito triste", analisa Estamira.

Mais uma vez, a imagem volta a ser preto em branco. Sob o lettering, "natal de 2001", imagens do aterro sanitário de Gramacho. A catadora explica: "Sacrifício é uma coisa, trabalhar é outra. Eu, Estamira, que vos digo ao mundo todo: trabalhar e não sacrificar". É nesse trabalho que ela interage com o melhor amigo, João. E é ele também que nos aponta a performance de Estamira diante da câmera. Com a imagem de volta às cores, ela tenta falar, mas é interrompida diversas vezes por ele. "Se retira, por favor! Eu não tô orientando ninguém nem quero orientar ninguém, eu tô alertando. Porque eu tenho a impressão...”. Mas, mesmo fora de quadro, João continua a interrompê-la, ao que ela, jocosa, responde com um gesto de socá-lo. Na sequência, entram imagens de João deitado ao relento, no aterro, e Estamira narra: "Ele é muito bom, o João. Eu tenho muita dó dele, ele é muito bom. Ele sabe ler e escrever muito e mesmo assim acontece essas coisa (SIC). É o trocadilho (SIC) que fez isso com as pessoas". Suas noções de fraternidade e do comum se devem, em sua visão, à necessidade de o "homem como único condicional". É o que sugere a sequência seguinte, na qual ela, sentada em um monte de lixo, filosofa: "O homem não pode ser incivilizado. Todos os homens têm que ser iguais, tem que ser comunista (SIC). Comunismo. Comunismo é a igualidade. Não é obrigado todos a trabalhar num serviço só. Não é obrigado todos comer (SIC) uma

iv O ano de 1986 foi marcado pela visualização do cometa de Halley, durante o mês de abril. Por ser um dos mais conhecidos cometas da história, sua visualização, possível a cada 76 anos, foi tema de grande destaque na mídia (Fonte: O Globo, disponível em http://acervo.oglobo.globo.com/fatos-historicos).

v De acordo com Dicionário Aurélio (1994, p. 436-7), o significado "comandante" não corresponde ao vocábulo "cometa". Porém, dentre os registros semânticos parta a palavra está a definição: "Pessoa que parece e desaparece rapidamente". 
coisa só. Mas a igualdade é a ordenança que deu quem revelou o homem, o único condicional. E o homem é o único condicional, seja que cor for. Eu sou a Estamira, eu não importo. Eu poderia ser da cor que fosse. Eu, formato homem par, mas eu sou a Estamira e eu não... Mas eu não admito, eu não gosto que ninguém ofende (SIC) cores nem formosura. O que importa: bonito é o que fez e o que faz; feio é o que fez e o que faz. Isso que é feio. A incivilização (SIC) é que é feio. Comunismo superior: o único comunismo".

As referências que a catadora faz à comunhão também descodificam o comungar do senso comum. É João quem aponta isso. Depois de uma panorâmica de entardecer no lixão, ele diz: "Quero mais é paz na minha vida. Paz. Sofrimento, nunca mais. Feliz natal!”. João ri (um natal feliz parece soar engraçado para ele) enquanto Estamira dorme. Na sequência seguinte, ela diz: "Eu, Estamira, visível e invisível. Eu tenho muitos sobrenomes e esses sobrenomes vêm de todo lugar". A catadora está em casa e sua fala nos aponta as diferentes contingências que nos valoram: situações que são colocadas sobre os nossos nomes. É aí que ela relata uma das contingências mais difíceis de sua vida: o tempo em que viveu com o vô materno, que estuprou sua mãe, abusou sexualmente dela e a entregou a um bordel: "Lamentavelmente, o pai da minha mãe é de famílias de Ribeiro, tudo polícia, tudo general, tudo não sei o quê. Ele é estuprador. Ele estuprou a minha mãe e fez coisa comigo. A minha depressão é imensa. A minha depressão não tem cura. E quando eu tinha nove anos e pedi pra ele comprar uma sandália... Eu queria uma sandália pra eu ir na festa... Ele falou pra mim que só comprava a sandália se eu deitasse com ele. Eu não gosto do pai da minha mãe porque ele me pegou com 12 anos e me trouxe para Goiás Velho e lá era um bordel. Era um bordel, sabe?! E eu prostituí lá. Era da filha dele. Aí, o pai do Hernani me conheceu lá onde o meu avô me deixou, lá no bordel. Aí eu já tinha 17 anos. E gostou demais de mim", conta Estamira. Mais uma vez, a catadora faz referência ao patriarcado - ao avô, ao pai e ao marido - que determina a condição do feminino. Mas reforça o fato de não se assujeitar a ele: "O pai do Hernani, ele era muito cheio de mulher. Daí eu não aguentei. Larguei tudo dentro da casa e só apanhei (SIC) o menino. Apanhei o menino e fui embora pra Brasília. Eu tava lá na casa da tia, lá em Brasília. Aí apareceu o pai da Carolina lá, o italiano. E levou eu (SIC) na casa dele. Aí deu certo e depois nós foi (SIC) morar junto. E ele também é cheio de mulher". Estamira não se submete ao que considera incorreto na relação marital. "Eu vivi com ele 12 anos, tive a Carolina e esse que eu fiz o cesário (SIC). Esse que fez o cesário nasceu invisível. E eu acho que o que mais me ajuda é esse que nasceu invisível”, conta Estamira, rompendo mais uma vez com o imaginário sobre o feminino ao afirmar que seu filho predileto é o que ela abortou.

Em mais uma passagem de tempo, o filme indica o natal de 2002. Em cores, as cenas mostram a confraternização na casa de Estamira, que canta com João trechos de músicas do cantor Roberto Carlos. O clima é de intimidade, fraternidade; todos riem e estão felizes. Porém, quando um dos netos de Estamira questiona sua crença em deus, ela se enfurece com o menino: "O que você sabe de deus? O que você sabe de deus? Você, que tá fedendo a ovo! Eu achava que você fosse mais inteligente! Você tem apenas 10 anos! A hora em que você ficar grande, você vai ver! Tomara que você fica grande! Tomara que você fica grande (SIC)!", ela diz, aos berros. O neto insiste na supremacia de deus e afirma que, sem a criação divina, Estamira não existiria. Ela se revolta: “O quê?! É ruim! Você me respeita! Eu não quero perder a paciência! Eu não quero perder a paciência porque você é meu neto! Você tá com deus enfiado no seu cu? Deus tá enfiado no seu cu pra falar isso pra mim? Eu tenho 62 anos, você quer saber mais de deus do que eu? Eu tenho dó da sua mãe, eu tenho dó da sua mãe porque fui eu que pari ela! Não foi deus que pariu a sua mãe não, fui eu que pari ela. Eu que pari, ó!”, grita a catadora. Nesse momento, ela tira a calça jeans na frente de todos e mostra a genitália para o neto. "Aqui, ó, fui eu que pari! Foi deus quem pariu a sua mãe não, foi eu (SIC)! Você pega teu Deus e vai pro caralho! Vai pro inferno, vai pro céu, vai pro caralho!”, ela diz, furiosa.

Na cena seguinte, mais calma, Estamira bebe cerveja e cantarola "você é doida demais, você é doida demais!", enquanto o neto conta para a mãe, Carolina, o que aconteceu. "Eu sou perfeita. Eu sou perfeita. Meus filhos são comum (SIC), eu sou perfeita! Eu sou melhor que Jesus e me orgulho por isso". Mais uma 
vez, entra o insert do coqueiro. Ela prossegue: "Se quiser fazer comigo pior do que fez com o tal de Jesus, pode fazer! A morte é maravilhosa. A morte é dona de tudo! A morte é dona de tudo! Deus: quem fez deus foi os homem (SIC).”. Aqui é um dos dois únicos momentos do filme em que Estamira, olhando ao redor, com ares persecutórios, parece, de fato, delirar, como se estivesse rodeada por seres invisíveis. A imagem remete diretamente à análise de Comolli sobre o 'risco' da mise-en-scène: "Filmar é, evidentemente, arriscar; é também, neste caso, arriscar-se, arriscar alguma coisa do seu lugar, de seu espectro subjetivo, nessa relação violenta com o outro que toda filmagem acaba sendo. [...] É preciso desejo e é preciso amor para fazer um filme, compreende-se. Ingênua seria, no entanto, a crença segundo a qual bastaria a esse desejo se mostrar, a esse amor se fazer sentir, para que as portas se abrissem e os sujeitos começassem a dançar. As vias da mise-en-scène são mais tortuosas. Nenhuma relação mediatizada por uma obra a ser fabricada, um risco a correr, uma máquina a ser convencida, nenhuma relação desse tipo é simples ou direta"².

De volta ao preto e branco, Estamira, em off, confessa: "Engraçado. Eu não sei se é por incrível que pareça a palavra certa... O que eu mais sinto falta na minha vida é a minha mãe. O que eu mais lembro na minha vida, minuto por minuto, é a minha mãe. Um dia, a minha mãe me perguntou assim: nenê, você já viu eles? E eu falei: que eles? Ela falou: eles é uma porção deles. Era os astros que atentava (SIC) ela. Eu sou do astro positivo, eu não sou do astro negativo. Sou dos astros positivo útil (SIC)”. A polaridade à qual Estamira se refere parece metaforizar o fato de ela não se identificar com a característica negativa do feminino. Nesse ponto, Carolina conta as maldades que o pai fazia com a mãe, principalmente o fato tê-la obrigado a internar a sogra (cujo nome era Rita Miranda Coelho) em um hospital psiquiátrico. Em off sobre uma sequência de fotos, a fala de Carolina é seguida de imagens documentais sobre o Hospital Psiquiátrico de Engenho de Dentro, no Rio de Janeiro, onde a mãe de Estamira ficou internada. Ela comenta o sofrimento da mãe, e Carolina conta os apelos que a avó fazia para que a filha a tirasse de lá - atitude que Estamira tomou no mesmo dia em que se separou do marido. "A minha avó ficou com a gente até morrer", conta Carolina que, no ônibus, ao acompanhar a mãe para uma consulta, fala sobre a impossibilidade de internar a mãe: "Para eu não carregar isso que ela carrega até hoje, eu sabendo dessa história, eu jamais tentei fazer isso", diz a filha da catadora.

De volta à casa, Estamira se lamenta: "A vida é dura, dura, dura. A vida não tem dó não. Ela é mau (SIC). Por mais que a gente peleja (SIC), que a gente quer bem, que a gente quer o bem... Fica destraviado (SIC)". Visivelmente dopada, ela reclama da medicação: “Aí, ó, tem coisa zoando no meu ouvido e eu acho que é os remédio (SIC), entendeu?! Porque eu bebo muito remédio, mas muito remédio. E eles tudo é dopante, esses remédio (SIC). Desgovernada. Eu tô desgovernada. Sabe o que é uma pessoa desgovernada? Querendo falar sem poder, agoniada”. A agonia de Estamira é não poder se expressar. Ela, então, tenta ler seu laudo médico: "Atesto que Estamira Gomes de Sousa, portadora de quadro psicótico de evolução crônica, alucinações auditivas, ideias de influência, discurso místico, deverá permanecer em tratamento psiquiátrico continuado". Mas ela questiona: "Eu acho que deficiência mental, quem temé imprestável, né?! Perturbação não é deficiência. Qualquer um pode ficar perturbado”. A perturbação de Estamira diante do mundo é análoga à reflexão deleuziana que, por meio do cinema, diferencia a capacidade lógica da potência do pensar. "O fato moderno é que já não acreditamos nesse mundo. Nem mesmo nos acontecimentos que nos acontecem, o amor, a morte, como se nos dissessem respeito apenas pela metade. Não somos nós que fazemos o cinema, é o mundo que nos aparece como um filme ruim. [...] É o vínculo do homem com o mundo que se rompeu. Por isso, é o vínculo que deve se tornar objeto de crença: ele é o impossível, que só pode ser restituído por uma fé. A crença não se dirige mais a outro mundo, ou ao mundo transformado. $\mathrm{O}$ homem está no mundo como numa situação ótica e sonora pura. A reação da qual o homem está privado só pode ser substituída pela crença. Somente a crença no mundo pode religar o homem com o que ele vê e ouve. É preciso que o cinema filme, não o mundo, mas a crença neste mundo, nosso único vínculo. [...] Cristãos ou ateus, em nossa universal esquizofrenia, precisamos ter razão para crer nesse mundo”7. 
As três mulheres da família se juntam. Solidárias, mãe e filhas manifestam as preocupações que têm umas com as outras. Entretidas com uma ninhada, Carolina fala da preocupação de Estamira com Maria Rita; Maria Rita fala do ressentimento de não ter sido criada pela mãe, de ter sido afastada dela. "Eu acho que eu sobreviveria com a minha mãe", diz a moça. A ideia de uma comunhão pela maternidade é, aqui, diferente do senso comum. Carolina conta que o trabalho da mãe no lixão melhorou sua saúde mental: "Às vezes, ela diz certas coisas que parecem verdade. Te deixam balançado. Mas o meu irmão não acha isso: o meu irmão acha que ela é totalmente possuída por uma força maligna”, conta Maria Rita. Corte para off de Hernani sobre imagens de culto em um templo da Igreja Adventista do Sétimo Dia. Ele diz que se distanciou porque a mãe blasfema contra Deus e a acusa de loucura e possessão demoníaca. "Eu falei com deus: só quero ter com a minha mãe quando o Senhor me der a certeza que ela tá perdoada e liberta pelo Senhor, porque o Senhor pode tudo".

Daí a montagem vai para um bonito take do amanhecer no lixão de Gramacho, com a silhueta de um cavalo e de cães contra o horizonte, intercalado por imagens de João e outros catadores dormindo no aterro sanitário. Estamira divaga: "Os homens estão pior (SIC) que os quadrúpulos (SIC), é uma decepção. A decepção de quem venerou o homem como o único condicional. Me dá uma tristeza, me dá vergonha, me dá nojo. O que eu faço? Olha, eu já tive vontade de desencarnar mas, se eu desencarnar, eu não cumpro a minha missão. A minha missão é revelar. Seja lá quem for. Doa a quem doer”. Um super close up, nos olhos de Estamira, dá continuidade à sua fala: "A minha cabeça trabalha muito, mas o trocadilo (SIC) fez com que eu me separasse até dos meus parentes. Eles não tão vendo também não. Eles tão igual Pilatos fez com Jesus. Já me bateram com pau pra mim (SIC) aceitar deus. Mas esse deus, desse jeito, esse deus deles, esse deus sujo, esse deus estuprador, esse deus assaltante, esse deus arrombador de casa... Com esse deus eu não aceito (SIC), nem picadinha a carne. Nem a minha carne picadinha de facão, de qualquer coisa. Eu não aceito, não adianta. Eu sou da verdade, eu sou a verdade. Os homem é o superior na terra, os bicho (SIC). Mas é superior. Trocadilo (SIC) fez isso. Agora vou revelar. Quem quiser me matar, pode matar. Não mataram Jesus? Jesus não é bom demais agora que ele morreu? Mas eu não". A insistência na revelação mostra que Estamira tenta ressignificar o mundo pelo absurdo que ele dá a ver, pela incongruência de suas relações, pela desumanidade banalizada. "A solução é fogo, a única solução éo fogo. Queimar tudo nos espaços, os seres, e por outros seres nos espaços”, ela diz, aludindo ao fogo como algo transformador. Sobre imagens do aterro de Gramacho nas quais há toneis em chamas (para queimar o gás que emana do material em decomposição), Estamira contradiz a devoção do filho Hernani a deus: "A terra disse. Ela falava. Agora é que ela tá morta. Ela disse que, então, ela não seria testemunha de nada. O que aconteceu com ela... Eu fiquei de mal com ela uma porção de tempo e falei pra ela que até que ela provasse o contrário. E ela me provou o contrário, a terra. Ela me provou o contrário porque ela é indefesa. A terra é indefesa. A minha carne, o sangue, é indefesa (SIC) como a terra. Mas eu, a minha áurea (SIC) não é indefesa não".

Sua identificação com uma das imagens mais fortes do feminino é explícita aqui: a terra. Mas ela vai além porque, mais que a terra, que é encerrada em sua corporeidade de astro, Estamira tem aura - ao passo que o filme Estamira aponta um valor de culto ${ }^{\text {ix }}$. Ambas, Estamira e a terra, aparecem como campos trabalhados, experimentados como indefesos diante de uma humanidade falida. "Se queima os espaço todinho (SIC) e eu tô no meio, pode queimar, eu tô no meio, invisível. Se queimar meu sentimento, minha carne, meu sangue... Se for para o bem, pela lucidez de todos os seres, para mim pode ser agora, nesse segundo. Eu agradeço ainda”, ela diz. Mais uma vez, há a referência ao fogo que transforma e consome. Mas o outro elemento tradicionalmente apontado como feminino, além da terra, é a água. É diante dela, em forma de ondas gigantescas, que o filme caminha para o desfecho. Nas sequências finais do documentário, em preto e branco, Estamira está na praia. Ao fundo, repete-se a música dos primeiros minutos da obra, quando ela se prepara para chegar no lixão. Dessa vez, a catadora caminha para o mar agitado e diz, em off: 
"Eu é (SIC) a Estamira. Eu não concordo com a vida. Eu não vou mudar meu ser. Eu fui visada assim, eu nasci assim e eu não admito as ocorrência que existe (SIC), que tem existido com os sanguíneos, carnifos (SIC), terrestre. Não gosto de erros, não gosto de suspeitas, não gosto de judiação, de perversidade, não gosto de humilhação, não gosto de imoralidade”.

\section{Considerações finais: o "trocadilo"}

Uma das questões mais presentes nas representações sobre o feminino é a maternidade. Na tessitura de Estamira, a maternidade emerge não só como laicização que se opõe explicitamente à imposição do sentido sagrado da "mãe", mas principalmente como experiência atravessada por uma violenta materialidade. Simbolizada pela separação entre Estamira e sua mãe, entre Estamira e seu 'filho invisível' (abortado) e entre Estamira e a filha Maria Rita, o documentário 'Estamira' aborda a histórica alienação de crianças de suas mães, que, desde o período colonial, é a história não revelada de uma dor secreta das mulheres. Característica da vida urbana, a atitude materna de 'abandonar' um filho sempre foi uma forma paradoxal de proteção à criança. Um paradoxo que, por moralismo ou miséria, atravessou a experiência de mulheres de diferentes camadas sociais ${ }^{12}$.

Apesar da óbvia assimetria desse atravessamento, ele também aparece, na história das mulheres, nas intervenções normatizadoras referentes à psiquiatria. Desde o fim do século XIX, a condição psiquiátrica foi relacionada à (in)capacidade física e moral das mulheres exercerem a maternidade. Nesse sentido, o parâmetro por excelência da 'loucura' feminina foi o corpo das mulheres no que se referia, principalmente, à procriação e ao sexo². Em 'Estamira', ambos, procriação e sexo, emergem de forma violenta, mas, ao mesmo tempo, emancipatórias: Estamira grita que ela, e não Deus, pariu sua filha "com sangue" e, depois que a filha Carolina credita a condição mental de Estamira à série de estupros que a mãe sofreu, a catadora é categórica ao afirmar que se recusa a acreditar no "Deus estuprador" cultuado pela sociedade. Especificamente sobre a intervenção normatizadora que sofre pela medicalização excessiva, Estamira critica de forma contundente a prática médica ao afirmar que os remédios receitados a ela "são dopante para querer deus falsário"13.

Estamira, o filme, não naturaliza o discurso esquizofrênico como exótico. Sua mise-en-scène faz aflorar um discurso desejante da autonomia sobre as intervenções normatizadoras de uma condição que é, simultaneamente, de gênero, mental e de classe - todas construídas ao longo da história. O cadáver de mulher que aparece no lixão (locus de Estamira e leitmotiv do documentário 'Estamira') é a síntese da brutalidade dessas intervenções, mas também é, esteticamente, o que Estamira não é, uma vez que ela não acata o apagamento social que lhe é imposto. No documentário 'Estamira', Estamira se coloca em cena como uma desconcertante consciência viva, potente e questionadora: poderia ser a representação do horror, mas é o belo em sua liberdade criativa. "Eu não gosto de falar lixo não. É cesto", ela corrige. Mas essa correção não é higienismo, e sim intervenção (subversão até), porque Estamira expressa suas condições concretas de existência pela violência de uma linguagem que nos coloca como catadores de restos de sentido. Sem moderação de linguagem, sem boas maneiras e sem reprimir seus excessos verbais, ela refuta o que, desde a Belle Èpoque, é imposição higienista às mulheres: fragilidade, recato, subordinação, afetividade sem consciência ${ }^{14}$.

Mesmo se contrapondo a este apagamento, o documentário Estamira não é, como já afirmado aqui, agrafia do outro: ao contrário, depende da escrita social, religiosa e médica para que seu discurso, pela transitividade, tenha significância. O que oprime a catadora (as materialidades que a atravessam) é também aquilo que ela desconstrói. Ao mesmo tempo que diz em terceira pessoa que "Estamira também é abstrata", afirma em primeira pessoa: "Eu, Estamira, visível e invisível. Eu tenho muitos sobrenomes $e$ esses sobrenomes vêm de todo lugar”. A linguagem e a mise-en-scène de Estamira são tangenciadas pela agressividade e têm tom afirmativo - qualidades historicamente associadas aos homens "de personalidade" e às mulheres tresloucadas. Estamira, o documentário, é escritura devido à mise-en-scene da catadora Es- 
tamira. O que ela coloca em cena, em relação com a câmera dirigida por Marcos Prado, se contrapõe a uma questão essencial sobre o feminino: o fato de a não-afirmação da mulher, reforçada por sua não-afirmação pelas palavras, ser a negação da subjetividade necessária à criação ${ }^{15}$. É assim que a protagonista subverte 0 que critica: o "trocadilo" ou o conjunto de valores que orientam a sociedade por meio de uma produção de sentido que falseia, desvia, cega e descarta.

Nas cenas finais de Estamira, Estamira solta os cabelos. "O fogo, ele está comigo agora. Ele tá me queimando, ele tá me testando. Sentimento, todos os astros têm sentimento. Esse astro aqui, a Estamira, não vai mudar o ser. Não vou ceder o meu ser a nada. Eu sou a Estamira e tá acabado. É a Estamira mesmo", ela diz. Reafirmando-se, mais uma vez, como sujeito, a catadora, agora, sorri. Brinca nas ondas, feliz. Está à beira d'água, o mar quebra nela, está agitadíssimo. Em off, sobre a imagem dela sorrindo, entra seu depoimento: "Eu nunca tive sorte. A única sorte que eu tive foi a de conhecer o Senhor Jardim Gramacho, o lixão, o Senhor Cisco no Entulho. E eu amo, eu adoro, como quero bem meus filhos, meus amigos. Eu nunca tive aquela coisa que eu sou: sorte boa”. Estamira fala com o mar, acena para as ondas, chama nomes, conversa sozinha. Está alegre. Parada, de costas para a câmera e em frente às ondas imensas, olhando o mar, em off, ela profere a penúltima fala do filme: "Tudo que é imaginado tem, existe. Sabia que tudo que é imaginado existe e é e tem? Pois é". A reflexão da catadora remete ao que Comolli afirma ser a única lógica do cinema: delirar. "A questão do cinema é, em última análise, se desfazer do que já está aqui: o mundo tal como se apresenta já dado, realizado e oposto ao filme. A lógica do cinema é absolutamente delirante: ela gostaria, ela quer que o mundo e seus gestos aconteçam unicamente no movimento do filme, na percepção do espectador, pela graça das emoções que as tornam críveis e fortes e tudo isso como se fosse pela primeira vez"2.

Seguem-se os créditos, que são interrompidos pela única participação do diretor, Marcos Prado, fora de quadro. Diante de Estamira, no lixão, ele pergunta: “O que a senhora quer fazer na praia?”. E Estamira, ela mesma um "trocadilo" de Estamira, leva para a mise-en-scène o que coloca em risco o teor documental do filme: "Eu quero posar lá", afirma.

\section{Referências}

1. Comolli JL. Sob o risco do real. Tradução de Paulo Maia e Rubem Caixeta. In: Catálogo forum.doc. bh 2001. Belo Horizonte: $5^{\circ}$ Festival do Filme documentário e Etnográfico do Forum de Antropologia, Cinema e vídeo; 2001. p. 99-108.

2. Comolli JL. Ver poder - A inocência perdida: cinema, televisão, ficção, documentário. Belo Horizonte: Editora UFMG; 2008.

3. Ricouer P. Tempo e narrativa. Tomo I. Campinas: Papirus; 2010.

4. Teixeira FE, org. Documentário no Brasil: tradição e transformação. São Paulo: Summus Editorial; 2004;

5. Instituto Brasileiro de Análises Sociais e Econômicas (Ibase) [internet]. Rio de Janeiro: Ibase; 2017 [citado em 2 jun 2017]. Disponível em: http://www.ibase.br.

6. Beauvoir S. O segundo sexo. Rio de Janeiro: Nova Fronteira; 2009.

7. Deleuze G. A imagem-tempo. Cinema II. Rio de Janeiro: Brasiliense; 2007.

8. Touraine A. O mundo das mulheres. Petrópolis: Vozes; 2007.

9. Paiva R. Política, palavra feminina. Rio de Janeiro: Mauad X; 2008.

10. Ricouer P. Discours e communication. Paris: Éditions de L'Herne; 2005.

11. Benjamin W. Coleção Os Pensadores. São Paulo: Abril Cultural; 1980.

12. Venâncio, RP. Maternidade negada. In. Del Priori M. História das mulheres no Brasil. São Paulo: Contexto; 2015. 
13. Engel, M. "Psiquiatria e feminilidade. In: Del Priori M. História das mulheres no Brasil. São Paulo: Contexto; 2015.

14. Soihet, R. Mulheres pobres e violência no Brasil urbano. In: Del Priori M. História das mulheres no Brasil. São Paulo: Contexto; 2015.

15. Telles, N. Escritoras, escritas, escrituras. In: Del Priori M. História das mulheres no Brasil. São Paulo: Contexto; 2015. 